\title{
ANALISA PENERAPAN MANAJEMEN RISIKO BAGIAN KREDIT PADA PT. BANK PERKREDITAN RAKYAT (BPR) LENGAYANG CABANG SURANTIH
}

\author{
Yanda Eka Putra, Romi Susanto \\ Akademi Keuangan Perbankan dan "Pembangunan" Padang \\ yandaekaputra541@gmail.com
}

\begin{abstract}
The purpose of this study was to find out how the analysis of the application of credit risk management of PT. BPR Lengayang branch Surantih. The research method used is the method of data analysis qualitative. The type of data used is secondary data obtained from Bank Indonesia and rural banks (BPR) Lengayang branch Surantih. The results of this study indicate that bad credit that occurs is caused by economic factors in the region that are not stable and weather factors do not occur.
\end{abstract}

Keywords :Risk management,credit risk,bad credit.

\section{PENDAHULUAN}

Bank merupakan lembaga yang sangat berpengaruh terhadap perekonomian suatu negara, terutama dalam sector perindustrian, perdagangan dan pertanian, dalam salah satu fungsinya bank sebagai intermediari merupakan perantara untuk terjadinya sebuah transaksi. MenurutUndang-Undang RI No.10 Tahun 1998 Bank adalah badan usaha yang mengimpun dana dari masyarakat dalam bentuk simpanan dan menyalurkannya kembali dalam bentuk kredit atau bentuk lainnyadalam rangka meningkatkan taraf rakyat banyak, sedangkan menurut (Hesti, 2018) Bank adalah lembaga intermediasi yang artinya, menghimpun dana dari masayarakat dalam bentuk simpanan dan dananya akan disalurkan kembali kepada masyarakat dalam bentuk pembiayaan atau dalam bentuk lainnya serta memberikan jasa yang dapat memenuhi kebutuhan kebutuhan masyarakat.

Menurut Undang-Undang RI No.10 Tahun 1998 BPR (Bank Perkreditan Rakyat) adalah bank yang melaksanakan kegiatan usaha secara konvesional atau berdasarkan prinsip syari'ah yang dalam kegiatannya tidak memberikan jasa dalam lalu lintas pembayaran. Salah satu produk dari BPR adalah menyalurkan kredit, setiap kredit yang disalurkan pasti akan mengalami resiko yang di sebut kreditbermasalah atau kredit macet.

Menurut Undang-Undang RI No.10 Tahun 1998 pengertian kredit adalah usaha penyediaan uang atau tagihan yang dapat dipersamakan dengan itu,perdasarkan persetujuan atau kesepakatan pinjam-meminjam anatara bank dengan pihak lainnya yang mewajibkan pihak peminjam untuk melunasi utangnya setelah jangka waktu tertentu dengan pemberian bunga. Sedangkan menurut (Amelia \& Marlius, 2018) Kredit adalah kemampuan untuk melaksanakan sesuatu 
pembelian atau mengadakan suatu pinjaman dengan suatu janji pembayaran akan dilakukan dengan ditangguhkan pada suatu jangka waktu tertentu yang telah disepakati.

Resiko kredit adalah resiko yang berkaitan erat dengan kemungkinan kegagalan debitur untuk melunasi hutangnya. Kredit bermasalah adalah kredit dimana debiturnya tidak mampu memenuhi prsyaratan yang telah di perjanjikan sebelumnya, seperti persyaratan mengenai pembayaran bunga, peningkatan margin deposito, pengembalian pokok pinjaman, pengeikatan dan peningkatan jumlah agunan dan sebagainya. Semakin banyak kredit yang disalurkan maka semakain besar resiko yang ditanggung oleh bank, untuk menjaga resiko kredit agar tidak bermasalah ataupun macet bank harus menerapkan prinsip 5C yaitu charakter, capacity, capital,collateral dan codition of economic. Dengan adanya penerapan pirinsip $5 \mathrm{C}$ guna meminimalisir resiko kredit.

PT. BPR Lengayang adalah perusahaan yang bergerak di bidang perbankan yang salah satu produknya adalah memberikan kredit kepada usaha dalam sekala kecil maupun menengah, PT. BPR Lengayang telah menjalankan tugasnya sebagai bank yang telah membantu perekonomian suatu negara yaitu dalam sektor pembangunan danbidang usaha lainnya.

Berdasarkan uraian tersebut, maka tujuan penelitian ini yaitu untuk mengetahui bagaimana analisa penerapan manajemen risiko bagian kredit pada PT. Bank Perkreditan Rakyat Lengayang Cabang Surantih.

\section{METODE PENELITIAN}

Metode penelitian yang digunakan ialah metode analisa data kualitatif. Dimana metode kualitatif menggambarkan dan menjelaskan data yang diteliti selama penelitian berlangsung pada PT. Bank Perkreditan Rakyat Lengayang Cabang Surantih.

\section{HASIL DAN PEMBAHASAN}

Menurut Sukma (2015) 5 C'S principle of Credit 5C ini merupakan salah satu alat atau tool utuk melihat sejauh mana kelayakan krdit yang akan diberikan kepada calon debitur dan dapat di pertanggung jawabkan.

Menurut Sukma (2015) Menyebutkan bahwa biasanya kriteria penilaian yang harus dilakukan oleh bank untuk mendapatkan nasabah yang benar-benar mengntungkan dilakukan dengan analisa 5C dan 7P.

PT. BPR Lengayang Cabang Surantih merupakan perusahaan yang bergerak dibidang pebankan yang mana kegiatan utamanya adalah menghimpun dana yang berupa simpanan dan menyalurkan dana dalam bentuk kredit, kredit yang disalurkan tentunya memiliki risiko kegagalan pengembalian kredit oleh debitur.

Berdasarkan analisa yang penulis lakukan dapat ditarik kesimpulan bahwa PT. BPR Lengayang Cabang Surantih telah menerapkan prinsip 5C dan 7P dalam mengantisipasi terjadinya kredit macet.

\section{Prinsip 5C dan 7P}

Prinsip 5C yang terdiri dari :

a. Charakter yaitu, sifat atau watak dan latar balakang calon debitur yang mengajukan kredit. Character dilihat pada saat wawancara yang dilakukan 
pihak bank oleh calon debitur apakah debitur layak atau tidak untuk diberikan kredit

b. Capacity yaitu, penilaian kreditur terhadap kemampuan debitur dalam memenuhi kewajibannya, jika bank menilai calon debitur tidak memiliki kemampuan maka kemungkinan bank akan melakukan penolakan kredit.

c. Capital yaitu, modal yang dimiliki oleh calon debitur yang mana lebih dikhususkan untuk debitur yang mengembangkan usahanya, maka bank dapat melihat laporan keuangan dari usaha debitur tersebut untuk penilaian kelayakan kredit.

d. Collateral yaitu, jaminan yang dijaminkan oleh debitur kepada bank atas kredit yang diajukannya. Jaminan akan menjadi pegangan bagi pihak bank, jika nasabah tidak bisa melunasi kreditnya maka bank akan melelang jaminan tersebut untuk menutup kerugian kredi tersebut, maka dri itu jaminan haruslah memiliki nilai yang lebih besar dari kredit yang di berikan. PT. BPR Lengayang Cabang Surantih sangat memperhitungkan jamian dari kredit yang di salurkan.

e. Conditon of economik yaitu kondisi perkonomian baik yang bersifat umum maupun khusus pada usaha masyarakat atau calon debitur.jika kondisi perekonomian kurang stabil maka pihak bank harus berhati-hati alam menyalurkan kredit.

Prinsip $7 \mathrm{P}$ yang terdiri dari :

a. Personality yaitu, penilaian bank terhadap kepribadian calon debitur atau tingkah lakunya yang memiliki hubungan dengan kredit yang nantinya diberikan. PT. BPR Lengayang Cabang Surantih melakukan surve yang tidak diketahui oleh calon debitur seperti berwawancara kepada tetangga yang menanyakan tetang kepribadian calon debitur.

b. Party yaitu, pengelompokan yang dilakukan oleh pihak bank berdasarkan kriteria atau golongan seperti berdasarkan modal yang dimiliki, kpribadian, loyalitas dan lain sebagainya. Berdasarkan golongan tersebut fasilitas kredit yang diberikan bankpun berbeda-beda berdasarkan kelompoknya.

c. Purpose yaitu, tujuan dari debitur atas kredit yang diajukan terhadap bank, bank harus mengetahui penggunaan dana olehcalon debitur, apakah untuk usaha, investasi atau untuk konsumtif.

d. Prospect yaitu, bagaimana prospect dari uasaha yang dijalankan oleh calon debitur, apakah usaha debitur tersebut memiliki propek yang baik kedepannya atau tidak. Prinsip ini berlaku pada debitur yang melakukan pinjaman untuk modal usaha.

e. Payment yaitu, penilaian bank terhadap calon debitur tentang kemampuan dalam membayar kredit yang nantinya disalurkan yang dilihat dari klancaran usaha dan prospek dari uashanya tersebut.

f. Profitabiliti yaitu, penilaian bank terhadap calon debitur bagamana kemampuan usahanya dalam memperoleh laba, prinsip ini hanya berlaku bagi debitur yang menggunakan dananya untuk modal usah.

g. Protection yaitu, anggunan yang di berikan debitur sangat diperhatikan oleh PT. BPR lengayang Cabang Surantih, karena jaminan ini yang dijadikan 
pegangan oleh bank sebagai salah satu cara untuk mengantisipasi kerugian yang terjadi akibat macetnya kredit.

Bagi PT. BPR Lengayang Cabang Surantih penerapan manajemen risiko dalam penyaluran kredit sangat penting peranannya karena stiap kredit yang disalurkan harus memenuhi kriteria bank seperti jaminan, karakter, usaha dan lain sebagainya yang berkaitan dengan pengembalian kredit nanatinya. PT. BPR Lengayang Cabang Surantih juga mepertimbangkan jumlah kredit yang disalurkan, bank melakukan penilaian terhadap debitur seberapa mungkin menurut bank yang bisa debitur untuk memenuhi kewajbannya, hal itu di tinjau dari usaha dan pendapatan calon debitur yang akan di beri kredit. Hal ini dilakukan guna mengurangi risiko kredit.

Selain itu PT. BPR Lengayang Cabang Surantih juga melakaukan pengawasan terhadap krdit yang disalurkan jika dana tersebut dipergunakan untuk usaha maka pihak bank akan melakukan tinjauan langsung kelapangan dan bisa juga mengajukan pertanyaan kepada debitur tentang usahanya tersebut, hal ini bertujuan untuk pengelompokan debitur nantinya jika kredit yang diberikan lancar maka debitur akan diberikan pinjaman lagi atau penambahan dana oleh pihak bank, PT. BPR Lengayang Cabang Surantih sangat memperhatikan nasabahnya yang melakukan pembayaran kredit yang lancar karena nsabah tersebut merupakan suatu asset bagi bank.

Setiap kredit yang disalurkan oleh bank tentunya tidak selalu lancar, begitupun dengan PT. BPR Lengayang Cabang Surantih ada beberapa faktor yang menyebabkan terjadinya krdit macet atau bermasalah yaitu sebagai berikut :

1. Terjadi karena faktor perekonomian yang tidak satbil, sebagian nasabah dari PT. BPR Lengayang Cabang Surantih merupakan petani gambir, yang mana gambir merupakan mata pencarian pokok bagi nasabah bank BPR tersebut. Karena jatuhnya harga gambir sangatlah berpengaruh bagi debitur PT. BPR Lengayang Cabang Surantih, tidak hanya berdampak pada bank saja namun juga berdampak pada seluruh sektor perekonomian didaerah surantih tersebut tepatnya.

2. Terjadi faktor cuaca yang buruk (hujan), hal ini juga sangat berpengaruh karena selain petani gambir sebagian nasabah bank tersebut juga berasal dari kalangan nelayan, pedagang, pengusaha batu bata, dan usaha lain sebagainya. Cuaca buruk merupakan suatu masalah bagi nasabah bank tersebut yang menyebabkan keterlambatan nasabah dalam memenuhi kewajibannya yaitu membayar angsuran kreditnya kepada bank.

3. Terjadi karea faktor kebutuhan pribadi debitur, terlambatnya debitur dalam membayar angsuran kreditnya karena didesak kebutuhan pribadi dari debitur tersebut seperti kebutuhan biaya sekolah dari anak debitur tersebut.

4. Terjadi karena faktor kegagalan usaha debitur, hal ini terjadi karena kredit yag disalurkan dulunya kepada debitur yang memiliki usaha yang maju dan lancar namun pada suatu keadaan diamana debitur tersebut jatuh dan bangkrut yang mengakibatkan debitur tidak mampulagi untuk mebayar kewajibannya kepada bank. 


\section{Kolektibilitas Kredit}

Berdasarkan ketentuan yang telah ditetapkan oleh Bank Indonesia NO. 31/147/KEP//DIR tanggal 12 November 1998, untuk melihat aktiva produktif bank dan seberapa jauh kredit bermasalah terdapat pada bank tersebut dinilai berdasarkan kolektibilitas kreditnya. Kolektibilitas kredit adalah keadaan pembayaran pokok, angsuran pokok dan bunga kredit oleh nasabah serta tingkat kemungkinan diterima kembalinya dana yang dinamakan dalam surat-surat berharga atau penanaman lainya.

Kolektibilitas kredit berdasarkan ketentuan Bank Indonesia adaah sebagai berikut:

1. Kredit lancar

Kredit lancar adalah kredit yang tidak mengalami penundaan pengembalian pokok pinjaman dan pembayaran bunga.

2. Kredit dalam perhatian khusus

Kredit dalam perhatian khusus adalah kredit yang mempunyai tunggakan pokok atau bunga telah mengalami penundaan selama 1 s/d 90 hari.

3. Kredit kurang lancar

Kredit Kurang Lancar adalah kredit yang pengembalian pokok pinjaman dan pembayaran bunganya telah mengalami penundaan selama $91 \mathrm{~s} / \mathrm{d} 180$ haridari jangaka waktu yang di sepakati.

4. Kredit diragukan

Kredit diragukan adalah kredit yang pengembalian pokok pinjaman dan pembayaran bunganya telah mengalami penundaan selama 181 s/d 270 hari atau dua kali jadwal yang telah ditetapkan.

5. Kredit macet

Kredit macet adalah kredit yang pengembalian pokok pinjaman dan pembayaran bunga telah mengalami pnundaan lebih dari satu tahun sejak jatuh tempo menurut jadwal yang telah diperjanjikan.

Penerapan yang dilakukan PT. BPR Lengayang Cabang Surantih dalam menangani kredit bermasalah yaitu sebagai berikut :

1. Pihak bank akan memberikan Surat Peringatan Pertama (SP1) kepda nasabah yang menunggak selama 1 s/d 90 hari yang diberikan bank melalui bagian pemasaran dana atau bagian pemasaran kredit, yang mana surat tesebut berisikan bahwasanya debitur telah terlambat dalam pembayaran angsuran kredit.

2. Setelah diberiak SP1 oleh bank kepada nasabah, namun untuk pembayaran yang selanjutnya juga terlambat maka bank akan memberikan SP2 kepada debitur tersebut atau dengan masa tunggakan 91 s/d 180 hari. Surat tersebut berisi tentang pemengilan debitur kekantor untuk menemui kepala cabang dengan tujuan mencari penyebab terjadinya keterlambatan debitur dalam pembayaran angsuran kredit dan memberikan solusi yang bisa diberikan bank seperti penambahan modal atau lain sebagainya.

3. SP3 diberiakan oleh bank kepada debitur yang telah memperoleh SP1 dan SP2 yang mana masa tunggakannya adalah 181 s/d 270 hari. SP3 ini berisikan bahwa debitur telah menunggak selama 18 hari atu lebih yang mana apabila debitur tidak melakukan pembayaran angsuran kredit maka pihak bank akan 
melakukan penarikan jaminan. Bank juga memberikan keringanan kepada debitur yang kreditnya bermasalah seperti memperkecil angsuran atau memperkecil bunga kredit dan bahkan bank akan bersedia untuk menghilangkan bunga dari kredit yang bermasalah tersebut dengan tujuan agar debitur bisa membayar angsuran kreditnya.

4. Penarikan jaminan oleh bank, hal ini dilakukan pihak bank jika debitur benarbenar sudah tidak mampu lagi untuk membayar kreditnya. PT. BPR Lengayang Cabang Surantih dalam melakukan penarikan jaminan debitur yang dilaksanakan oleh kepala cabang PT. BPR Lengayang dan perwakilan oleh kepala pusat dari kantor pusat BPR Lengayang. Adapun kredit yang macet yang debiturnya mau membayar seberapa ia mampu dalam satu bulan sekali pembayaran yang ditagih oleh bagian pemasaran kredit.

Dengan adanya kredit bermasalah tersebut pihak bank tentunya melakukan tagihan kepada debitur yang bermasalah, dalam proses penagihan pihak bank mendapat komplen dari debitur yaitu sebagai berikut:

1. Debitur merasa bahwasanya kreditnya belum tergolong kedalam kredit bermasalah, sehingga pihak bank harus memberikan bukti dan menjelaskan dengan baik keepada debitur yang mana kredit dari debitur tersebut sudah bermasalah dan juga alasan-alasan dan cara bicara dari debitur yang membuat pihak bank harus lebih bersabar dalam menghadapinya.

2. Pada saat penarikan jaminan, pihak bank telah memberikan solusi kepada debitur kredit yang macet tersebut seperti memberikan keringanan dengan membayar pokok saja namun debitur merasa ia belum mendapat peringatan oleh bank sehingga debitur komplain terhadap bank tentang penyitaan jaminan tesebut.

Pihak bank harus lebih berhati-hati dalam memberikan kredit kepada nasabah, bank harus memperatikan calon debitur yang akan diberikan kredit karena kredit yang disalurkan merupakan suatu risiko bagi bank oleh karena itu risiko tersebut harus dikelolah dengan cara hal ini bertujuan untuk mengantisipasi terjadinya kredit bermasalah atau macet.

\section{SIMPULAN}

Berdasarkan penelitian yang penulis lakukan di PT. BPR Lengayang Cabang surantih penulis menyimpulkan bahwa, PT. BPR Lengayang Cabag Surantih merupakan industri yang bergerak dibidang perbankan, yang mana kegiatan utamanya adalah menghimpun dan menyalurkan dana kepada masyarakat. PT. BPR Lengayang Cabang Surantih telah menerapkan prinsip 5C dan 7P dalam menyalurkan kredit, hal ini bertujuan untuk mengurangi terjadinya kredit bermasalah. Namun demikian dalam sebuah perbankan tentunya ada saja yang membuat terjadinya kredit macet seperti halnya yang terjadi pada PT. BPR Lengayang Cabang Surantih. Kredit macet yang terjadi disebabkan oleh faktor perekonomian yang tidak satbil, faktor cuaca yang buruk (hujan),faktor kebutuhan pribadi debitur dan faktor kegagalan usaha debitur, dari ke empat faktor tersebut yang paling dominan adalah faktor perekonomian daerah yang tidak satbil dan faktor cuaca buruk (hujan) kedua faktor ini saling keterkaitan debitur dari PT. BPR Lengayang Cabang Surantih rata-rata adalah para petani gambir sedangkan 
harga gambir saat ini turun hal ini sangat berpengaruh terhadap kredit yang telah disalurkan bank, belum lagi pengaruh dari cuaca buruk yang mana hasil dari panen petani tersebut tidak kering yang mengakibatkan debitur terlambat dalam membayar angsuran kreditnya.

Denagan adanya kredit macet bank tentu melakukan cara untuk menagani hal tersebut, PT. BPR Lengayang Cabang Surantih melakukan penanganan kredit macet tersebut dengan cara sebagai berikut:

1. Memberikn SP1 kepada debitur yang menunggak selama $1 \mathrm{~s} / \mathrm{d} 90$ hari.

2. Memberikan SP2 kepada debitur yang menunggak selama $91 \mathrm{~s} / \mathrm{d} 180$ hari.

3. Memberikan SP3 kepada debitur yang menunggak selama 181 s/d 270 hari.

4. Melakukan penarikan jaminan oleh bank yang dikarenakan ketidak mampuan debitur dalam melunasi kreditnnya.

\section{UCAPAN TERIMA KASIH}

Terimakasih penulis sampaikan kepada :

1. Kedua Orang Tua yang senantiasa memberikan dukungan baik secara moril maupun materil.

2. Direktur AKBP beserta prodi AKBP yang telah memberikan kesempatan kepada penulis untuk melakukan penelitian ini.

3. Dosen Pembimbing tugas akhir yang telah memberikan arahan dan bimbingan hingga tugas akhir ini bisa terselesaikan.

4. Pimpinan PT. BPR Lengayang Cabang Surantih yang telah mengizinkan penulis dalam memperoleh informasi beserta pengambilan data.

5. Semua Pihak yang telah memberikan dukungan dan bantuannya dalam penyelesaian tugas akhir ini.

\section{DAFTAR PUSTAKA}

Afriyeni, A., \& Putra, Y. E. (2019). Analisis Faktor-Faktor Yang Mempengaruhi Tingkat Pengembalian Kredit Usaha Rakyat (KUR) PT. Bank Rakyat Indonesia (BRI) Unit Talang Cabang Solok. https://doi.org/10.31219/osf.io/crfpg

Afriyeni, A., \& Susanto, R. (2019). Analisis Pengaruh Pemberian Kredit Terhadap Loan To Deposit Ratio dan Dampaknya Pada Pendapatan (Studi Pada PT BPR Lengayang Pesisir Selatan). https://doi.org/10.31219/osf.io/mnbtv

Alanshari, F., \& Marlius, D. (2018). Prosedur Pemberian Kredit KPR Pada PT. Bank Tabungan Negara (Persero) TBK Cabang Pembantu Bukittinggi. https://doi.org/10.31227/osf.io/rsfhc

Amelia, L., \& Marlius, D. (2018). Pengendalian Kredit Dalam Upaya Menciptakan Bank Yang Sehat Pada PT. Bank Pembangunan Daerah Sumatera Barat Cabang Utama Padang. https://doi.org/10.31227/osf.io/kpc64 
Andriani, B., \& Susanto, R. (2019). Pengawasan Kredit PT. Bank Perkreditan Rakyat (BPR) Ophir Pasaman Barat. https://doi.org/10.31219/osf.io/aunvc

Febriati, E. C. (2011). Analisis Penerapan PSAK 55 Atas Cadangan Kerugian Penurunan Nilai. Jurnal Emba, 1(3), 207-217.

Hesti, Y. (2018). Analisis Yuridis Tujuan dan Kewenangan Otoritas Jasa Keuangan (OJK) Dalam Lembaga Perbankan Di Indonesia. Jurnal Pranata Hukum, 13(2), 181-186.

Shanjaya, A. R., \& Marlius, D. (2017). Peranan Laporan Keuangan Dalam Kebijaksanaan Pemberian Kredit Kepada Calon Nasabah Pada PT. BPR Batang Kapas. https://doi.org/10.31227/osf.io/uxmg6

Sukma, D. A. (2015). Analisis Kelayakan Penilaian Kredit Menggunakan Metode Analisa 5C Sebagai Penunjang Keputusan Kredit Pada PT. BPR Hariarta Sedana. Teknik Informatika Universitas Islam Syekh Yusuf Tangerang, (3), 395-401.

Undang-undang RI No. 10. (1998). Undang-undang Republik Indonesia Nomor 10 Tahun 1998 Tentang Perubahan Atas Undang-Undang Nomor 7 Tahun 1992 Tentang Perbankan.

Widayati, R. (2019). Pelaksanaan Prinsip Kehati-Hatian Dalam Pemberian Kredit Konsumtif Pada Bank Nagari Cabang Siteba. https://doi.org/10.17605/OSF.IO/FZVXR

Widayati, R. (2019). Aktivitas Pemberian Kredit Komersil Pada Bank Nagari Cabang Sijunjung. https://doi.org/10.17605/OSF.IO/QTVZ9

Widayati, R. (2019). Pelaksanaan Kredit Pada Bank Perkreditan Rakyat LPN Pasar Baru Durian Sawahlunto. https://doi.org/10.17605/OSF.IO/5HPAB

Yulita, A. (2014). Analisi Pengaruh Faktor Makro Ekonomi Terhadap Tingkat Kredit Bermasalah Pada Bnak Umum Di Indonesia. 